\title{
The Link Between Innovation Behaviors and Productivity Strategies of Enterprises in Albanian Economic Growth
}

\author{
Güngör Turan \\ PhD in Economics, Epoka University, Albania, gturan@epoka. edu. al \\ Irma Gjana \\ (corresponding author) PhD Cand. in Business Administration, \\ Epoka University, Albania, irmagjana@gmail.com
}

\begin{abstract}
The paper primarily aims to provide a link between the innovation behaviors and productivity levels of enterprises in Albania, which are the main source of job creation and employment in economic growth, as well as underscore the importance that the innovation behaviors and productivity strategies of enterprises play in Albanian growth in the long-run. The regression model developed and Johansen co-integration test applied on the data of GDP per worker and the number of created jobs or employed in 1991-2013, are investigated with the scanted literature throughout the study.
\end{abstract}

Keywords: innovation, productivity, Albania.

JEL: Classification L26 $\cdot \mathrm{L} 60 \cdot 031 \cdot 033$

\section{Introduction}

Today, worldwide, innovation and productivity play a crucial role in economic development. European Union has shown a good performance in developing strategies and programs for each of its countries in research and innovation. The increase of funds in the innovation and R\&D, are resulting in an increase in productivity and in job creation and leads the Union countries in long term economic growth rates. Despite the strategies and many other initiatives taken, Albania has made very little progress in the field, and/so research and innovation still remains one of the priority tasks of Albanian government. In a challenging global world, Albania has now the opportunity to access innovative technologies. It has the possibility to use the financial and non financial help of international funds, as well as the possibility of a bigger market that channels to the increase of the quality of services and economic development.

According to the World Bank (2013), Albania has a lot to do in order to efficiently benefit from the time and place given its strategic circumstances. The reinforcement of $R \& D$ infrastructure and public research institutions, the increase on the R\&D and innovation spending, and the investment on the human resources and education are some of the main fields where Albania needs to improve. Albania underwent a transition period to market economy, and today it faces different challenges in economic development. Small and medium-sized enterprises (SMEs) dominate the sector, and are the main contributors in the country's economic growth. According to INSTAT (2013), SMEs occupy $99.8 \%$ of the total numbers of firms in Albania, and they generate $81 \%$ of employment and $70 \%$ of added value. (European Commission; Enterprise and Industry/SBA Fact Sheet 2013/ Albania)

Despite adopting international strategies and, changing much legislation and other initiatives, Albania has made very little progress in the field of innovation. In the 2014 Global Innovation Index, Albania stands last, in the $94^{\text {th }}$ place, in relation to the position of other European and regional countries. (The Global Innovation Index 2014, the Human Factor in Innovation)

According to different studies, small firms are said to be the engines of technological and innovative change. As most major firms in Albania are of that kind, a lot of effort must be spent to increase the research and innovation in SMEs, and to derive from them the best and the highest productivity results. 
The remainder of the paper is organized as follows: literature review of linking between innovation, productivity of enterprises and economic growth; regression model and data specification for implementing of Johansen co-integration and Granger causality method to test long-run relationship on the topic; and conclusion.

\section{Literature Review}

The relationship between innovation, productivity, and growth, and especially, the measurement of effects that innovative activities have on firms' productivity and economic growth, has been an area of great interest for researchers. Different empirical studies, including Hall et al. (2009) on Italy, Mairesse and Mohnen (2005) on France, Janz et al. (2004) on Germany, and Loof and Heshmati (2002) on Sweden, have shown that the effect of innovation on productivity is positive.

Hall et al. (2009), developed a structural model of innovation, where information on innovation and productivity measures gave light to some peculiar features that innovation shows in SMEs, particularly in Italian SMEs. According to this study, process and product innovation have a positive impact on a firm's productivity.

In firm level studies such as Mairesse and Mohnen's (2005) on France, Janz et al. 's (2004) on Germany, Loof and Heshmati's (2002) on Sweden, the R\&D effect on productivity is found to be positive. The majority of these studies depends on the production - function approach, and includes R\&D as an input to production.

The importance of SMEs in the economic development of the country as a main source of national income and as an important area for employment and entrepreneurship is undeniable. SME's importance in Albania is also field in some scientific research such as, Mucollari et al. (2012) and Keskin \& Senturk (2010).

According to Mucollari et al. (2012), the SMEs are the backbone of the Albania economy and have an important role in bringing on innovative products and techniques. In the other hand Keskin \& Senturk (2010), have shown the importance of SMEs by means of SWOT analysis of SMEs sector in Albania, and by comparison of this sector with the one in Turkey.

The SMEs are very important as implementers of innovation and therefore as a catalyst for important steps toward national development. In Albania, more needs to be met in the context of improving the national strategy, infrastructure, and technology policies of innovation to benefit from the important source of its SMEs, which are considered the backbone of economy. At this point, researchers and international organizations operating in Albania have focused on the importance of concrete regulations needed to be implemented in order to reach targeted developments. Shkurti (2013), Scalera \& Uruci (2011), IDRA (2011), Bahiti \& Shahini (2010), Xhepa (2006), yield gaps at various points, such as; lack of well established national strategy and technology policies on innovation, limited resources, poor infrastructure, competing against experienced giants, hard crisis time, etc. All researches underscore the idea that special importance should be given to R\&D strategy for innovation, as to use the financial and non financial help of international funds to increase the quality of services and economic development of Albania.

\section{Research Model and Methodology}

This part is organized as follows: the regression model and data specification performed in the study; descriptive statistics of the variables; Johansen co-integration tests; the co-integration of GDP per worker and the number of employed (the number of created jobs) by carrying out a univariate analysis, and, lastly, the Granger causality test.

\section{1 Model and data specification}

This is the regression equation model performed in this paper:

$G D P$ per worker $=\alpha+\beta_{1} E M P+\varepsilon$

Where a represents the intercept, $\beta_{1}$ represents the estimated regression coefficient, and $\varepsilon$ is the error term. 
The dependent variable in the equation is $G D P$ per worker, and it represents labor productivity and growth, which are measured by a firm's contribution to a country's GDP growth (Praag \& Versloot, 2007). Therefore, in this paper it is used as a measure of a firm's labor productivity in the form of a firm's contribution to the GDP per worker.

The independent variable EMP represents the total number of employed, which is the measure of the number of created jobs in the economy. Employment indicates that firms may contribute to the number of employment. Firm growth, is measured by the number of jobs created (Praag \& Versloot, 2007). Therefore, it is used as an indicator of the quantity of employment created by enterprises in the economy.

The data consist of yearly data obtained from the Worldbank database (http://dataworldbank, accessed: 20 March 2015) for Albania in 1991-2013. All tests are performed by using E Views7 statistical program.

\section{2 Descriptive statistics}

The following graphs diagrammatically represent the data. Tables and figure show descriptive statistics of the data and regression output. According to the regression output, GDP $=19326614.5934-13364.5941937^{\star} E M P$ is the estimated regression model.

Graph 1. GDP per worker

GDP

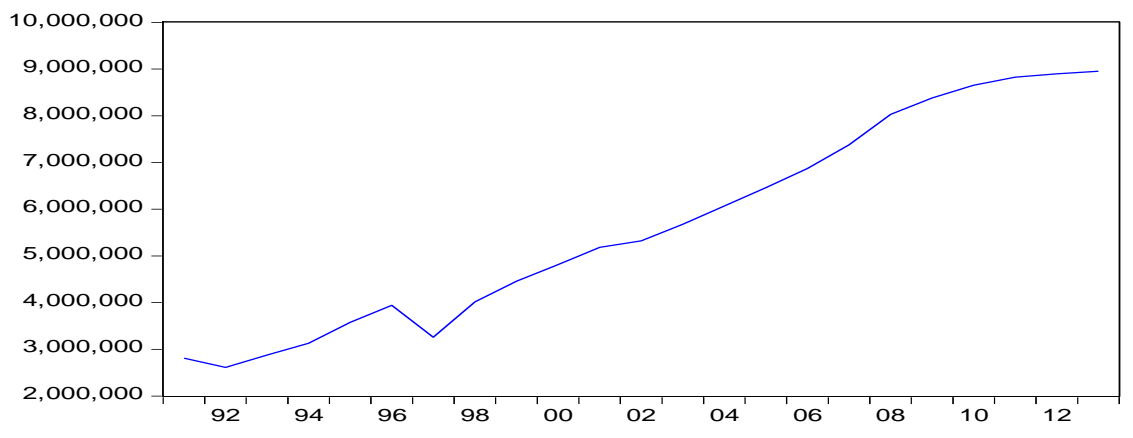

Graph 2. The number of employed

\section{EMP}

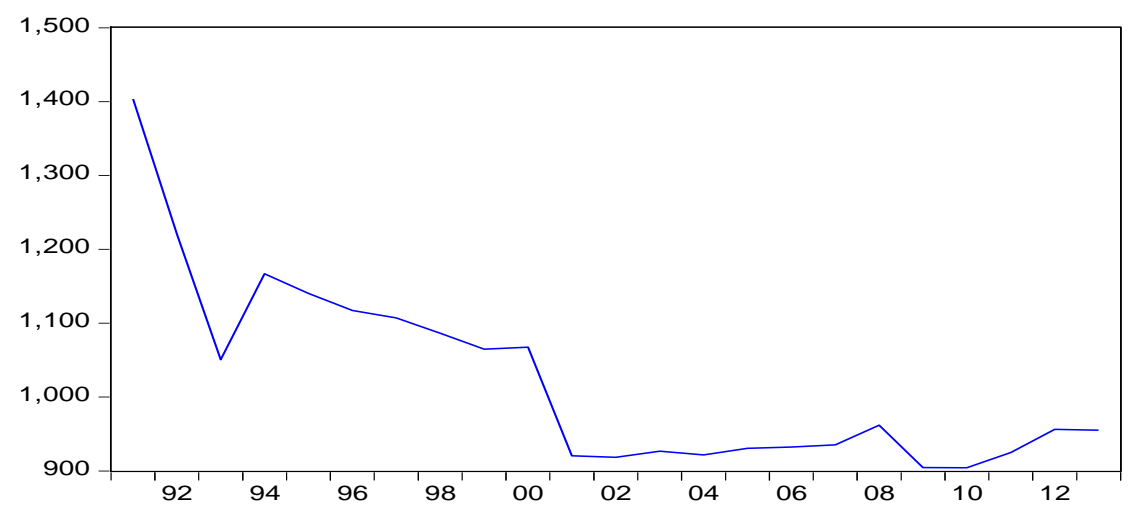


Table 1. Descriptive statistics of variables

GDP EMP

\begin{tabular}{lll} 
Mean & 5660672. & 1022.548 \\
Median & 5321147. & 956.3580 \\
Maximum & 8954597. & 1403.496 \\
Minimum & 2612719. & 904.4240 \\
Std. Dev. & 2219423. & 127.6608 \\
Skewness & 0.190828 & 1.302560 \\
Kurtosis & 1.625085 & 4.387640 \\
Jarque-Bera & 1.951218 & 8.349188 \\
Probability & 0.376963 & 0.015381 \\
Sum & $1.30 \mathrm{E}+08$ & 23518.61 \\
Sum Sq. Dev. & $1.08 \mathrm{E}+14$ & 358539.9 \\
Observations & 23 & 23 \\
\hline
\end{tabular}

Table 2. Regression output

Dependent Variable: GDP

\begin{tabular}{lllll}
\hline \hline Variable & Coefficient & Std. Error & t-Statistic & Prob. \\
\hline \hline C & 19326615 & 2499550. & 7.732038 & 0.0000 \\
EMP & -13364.59 & 2426.412 & -5.507966 & 0.0000 \\
\hline \hline R-squared & 0.590944 & Mean dependent var & 5660672. \\
Adjusted R-squared 0.571465 & S. D. dependent var & 2219423. \\
S. E. of regression & 1452892. & Akaike info criterion & 31.29895 \\
Sum squared resid & $4.43 E+13$ & Schwarz criterion & 31.39769 \\
Log likelihood & -357.9379 & Hannan-Quinn criter. & 31.32378 \\
F-statistic & 30.33769 & Durbin-Watson stat & 0.466510 \\
Prob (F-statistic) & 0.000018 & &
\end{tabular}


Figure 1. Histogram and statistics of variables

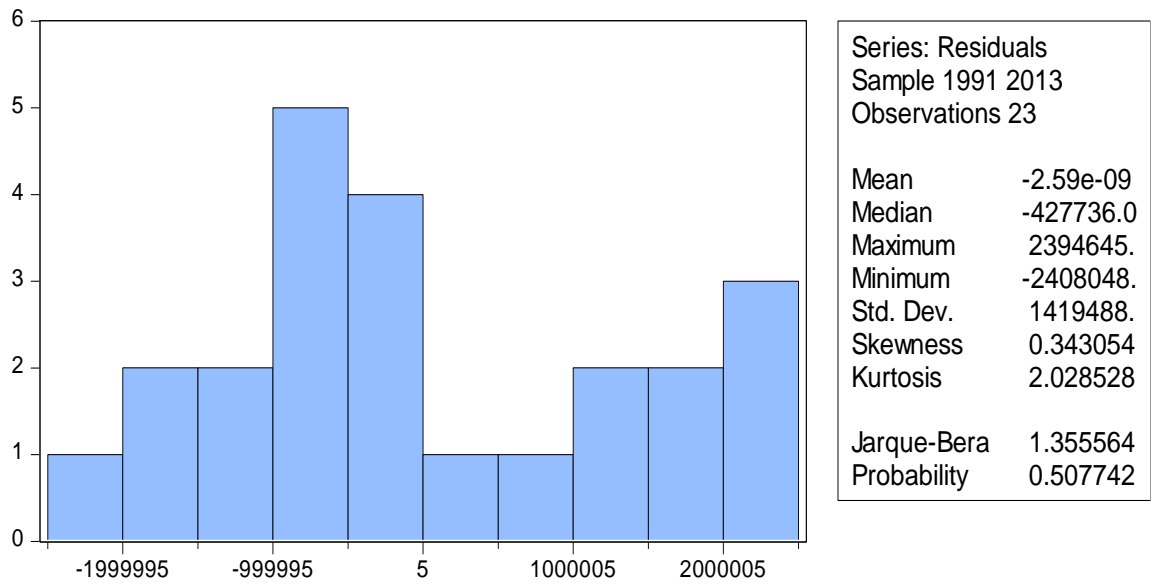

\section{3 Johansen co-integration test}

The time series data display a variety of behavior. The main reason why it is important to know whether a time series is stationary or non-stationary before one embarks on a regression analysis is that there is a danger of obtaining apparently significant regression results from unrelated data when non-stationary series are used in regression analysis. Such regressions are said to be spurious (Hill et al. , 2008). Before analyzing the co-integrating relationship between GDP per worker and employment, it is important to carry out a univariate analysis. The economic series like those of GDP and employment tend to possess unit roots. The presence of unit roots in the underlying series points towards the non-stationary of the underlying series. If both the independent and the dependent variables show the presence of unit roots, the regression results do not hold much meaning. This is referred to as spurious regression, whereby the results obtained suggest that there are statistically significant relationships between the variables in the regression model. However, in fact, all that is obtained is the evidence of contemporaneous correlation, rather than a meaningful causal relation. The problem of spurious regression is compounded by the fact that the conventional $\mathrm{t}$ - and F-statistics do not have standard distributions generated by stationary series; with non-stationary, there is a tendency to reject the null in both cases and this tendency increases with sample size (Gül \& Acıkalın, 2008). The stationary of each series was investigated by employing the unit root tests developed by Dickey and Fuller. The test consists of regressing each series on its lagged value and lagged difference terms. The number of lag length is based on the SIC information criterion.

Table 1. ADF unit root (level) and first differences test results of GDP variable

Null Hypothesis: GDP has a unit root

Exogenous: Constant

Lag Length: 0 (Automatic - based on SIC, maxlag=4)

\begin{tabular}{lcc}
\hline \hline & t-Statistic & Prob. * \\
\hline \hline Augmented Dickey-Fuller test statistic & 0.173514 & 0.9642 \\
\hline Test critical values: 1\% level & -3.769597 & \\
& & \\
& & \\
& & \\
& & \\
& &
\end{tabular}




$\begin{array}{ll}5 \% \text { level } & -3.004861 \\ 10 \% \text { level } & -2.642242\end{array}$

Exogenous: Constant, Linear Trend

Augmented Dickey-Fuller test statistic

-2. 910469

0.1782

\begin{tabular}{cc}
\hline Test critical values: $1 \%$ level & -4.440739 \\
$5 \%$ level & -3.632896 \\
$10 \%$ level & -3.254671 \\
\hline \hline
\end{tabular}

Null Hypothesis: D (GDP) has a unit root

Exogenous: Constant

\begin{tabular}{ccc}
\hline \hline Augmented Dickey-Fuller test statistic & -5.191666 & 0.0005 \\
\hline Test critical values: $1 \%$ level & -3.788030 & \\
$5 \%$ level & -3.012363 & \\
$10 \%$ level & -2.646119 & \\
\hline \hline
\end{tabular}

Null Hypothesis: D (GDP) has a unit root

Exogenous: Constant, Linear Trend

\begin{tabular}{ccc}
\hline \hline & t-Statistic & Prob. ${ }^{*}$ \\
\hline \hline Augmented Dickey-Fuller test statistic & -4.966352 & 0.0036 \\
\hline Test critical values: $1 \%$ level & -4.467895 & \\
$5 \%$ level & -3.644963 & \\
$10 \%$ level & -3.261452 & \\
& & \\
\hline \hline
\end{tabular}

*MacKinnon (1996) one-sided p-values.

Tables 1 and 2 reports the Augmented Dickey-Fuller (ADF) test statistics under the null hypothesis of a unit root (level) and first differences of variables of GDP and EMP. This table also presents the number of lag lenghth included in the regression. The hypothesis of unit root against the stationary alternative is not rejected at all levels for GDP per worker variable with constant and linear trend. The ADF test of GDP per worker variable gives the unit root at all levels. Therefore, first differences of that variable are taken and it is shown that GDP per worker data are stationary now. Hence, it has been concluded that these variables are integrated of order 1. Also, the ADF test results of the

EMP variable gives unit root at $1 \%$ level with constant and linear trend, and taking first differences that variable is stationary and integreted of order 1. 
Table 2. ADF unit root (level) and first differences test results of EMP variable

Null Hypothesis: EMP has a unit root

Exogenous: Constant

Lag Length: 0 (Automatic - based on SIC, maxlag=4)

\begin{tabular}{ccc}
\hline \hline & t-Statistic & Prob. * \\
\hline \hline Augmented Dickey-Fuller test statistic & -3.919682 & 0.0072 \\
\hline Test critical values: $1 \%$ level & -3.769597 & \\
$5 \%$ level & -3.004861 & \\
$10 \%$ level & -2.642242 & \\
& & \\
\hline
\end{tabular}

Null Hypothesis: EMP has a unit root

Exogenous: Constant, Linear Trend

t-Statistic Prob. *

\begin{tabular}{ccc}
\hline \hline Augmented Dickey-Fuller test statistic & -3.794931 & 0.0366 \\
\hline Test critical values: $1 \%$ level & -4.440739 \\
$5 \%$ level & -3.632896 \\
$10 \%$ level & -3.254671 \\
\hline
\end{tabular}

Null Hypothesis: D (EMP) has a unit root

Exogenous: Constant

t-Statistic Prob. *

\begin{tabular}{ccc}
\hline \hline Augmented Dickey-Fuller test statistic & -4.995734 & 0.0007 \\
\hline Test critical values: $1 \%$ level & -3.788030 \\
$5 \%$ level & -3.012363 \\
$10 \%$ level & -2.646119 \\
\hline \hline
\end{tabular}

Null Hypothesis: D (EMP) has a unit root

Exogenous: Constant, Linear Trend

t-Statistic Prob. *

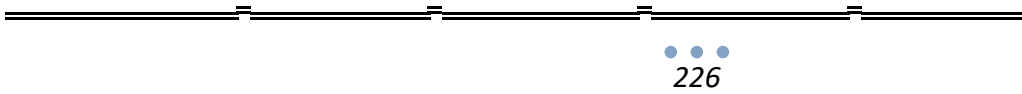


Augmented Dickey-Fuller test statistic

$-5.068295 \quad 0.0030$

Test critical values: $1 \%$ level

$-4.467895$

$5 \%$ level

$-3.644963$

$10 \%$ level

-3. 261452

*MacKinnon (1996) one-sided p-values.

On the basis of the above-mentioned unit root tests, the Johansen's co-integration test was performed to see whether any combinations of the variables are co-integrated. Johansen (1988), and Johansen and Juselius (1990) have identified cointegration analysis. This approach uses a maximum likelihood procedure that tests for the number of co-integration relationships and estimates the parameters of those co-integrating relationship.

LR test statistics and critical values are shown in Table 3. The results of both trace and max-eigen value tests suggest that there is no long-run co-integrating relationship between variables at the $5 \%$ significance level. In other words, a long-run stable relationship between variables does not exist.

Table 3. Johansen co-integration test results

Unrestricted Cointegration Rank Test (Trace)

\begin{tabular}{lllll}
\hline \hline $\begin{array}{l}\text { Hypothesi } \\
\text { zed }\end{array}$ & Trace & 0.05 & \\
$\begin{array}{l}\text { No. of CE } \\
\text { (s) } \quad \text { Eigenvalue }\end{array}$ & Statistic & Critical Value & Prob. * \\
\hline \hline None & 0.350326 & 9.892522 & 15.49471 & 0.2891 \\
At most 1 & 0.039007 & 0.835551 & 3.841466 & 0.3607 \\
\hline \hline
\end{tabular}

Unrestricted Cointegration Rank Test (Maximum Eigenvalue)

\begin{tabular}{lllll}
\hline \hline $\begin{array}{l}\text { Hypothesi } \\
\text { zed }\end{array}$ & Max-Eigen & 0.05 & \\
$\begin{array}{l}\text { No. of CE } \\
(\mathrm{s}) \quad \text { Eigenvalue }\end{array}$ & Statistic & Critical Value & Prob. * \\
\hline \hline None & 0.350326 & 9.056971 & 14.26460 & 0.2814 \\
At most 1 & 0.039007 & 0.835551 & 3.841466 & 0.3607 \\
\hline \hline
\end{tabular}

*MacKinnon-Haug-Michelis (1999) p-values 


\section{4 Granger causality test}

Table 4 presents the results of Granger causality test. The results of the co-integration test have been confirmed by the Granger causality test results. Because the P values are greater than 0. 05, both "EMP does not Granger Cause GDP" and "GDP does not Granger Cause EMP " are accepted. Therefore, the pair wise Granger causality test confirms the result of the Johansen co-integration test results of no co-integration between variables in Albania in the long run.

Table 4. Pairwise Granger Causality Tests Results

\begin{tabular}{lccl}
\hline \hline Null Hypothesis: & Obs & F-Statistic & Prob. \\
\hline \hline EMP does not Granger Cause GDP & 21 & 1.09638 & 0.3579 \\
GDP does not Granger Cause EMP & & 0.83397 & 0.4523
\end{tabular}

\section{Conclusion and recommendations}

This paper empirically analyzes the co-integration of the long-run relationship between GDP per worker as measure of labor productivity levels of enterprises and the number of employed as a measure of jobs created by enterprises in Albanian growth. Since one of the variables is non-stationary and presents unit root, Johansen's co-integration method has been applied. This methodology has allowed for obtaining of a long-run co-integrating relationship among these variables. The co-integration results provide evidence of a no co-integrated vector. This indicates that the GDP per worker and the number of employed does not move together in the long run. Labor productivity is the main source of increases in GDP per worker in Albanian growth. But labor productivity levels of enterprises are not enough for sustainable long-term economic growth in Albania. Therefore, enterprises must exhibit more innovative behaviors and productivity strategies by using efficient production technology-physical capital and human capital-skilled labor force to create enough number of jobs for higher and rapid growth. In the long-term it can be seen that sustainable economic growth generates higher GDP per worker and the number of created jobs at the same time.

\section{References}

[1] Bahiti, R. , Shahini, B. , (2010). Strengthening innovation and technology policies for SME development in Albania, Contemporary economics. Vol. 4, 1, 191-205.

[2] Dutta, S. , Lanvin, B. , \& Wunsch-Vincent, S. , (Eds. ), (2014). Global Innovation Index. The Humman Factor in Inovvation, Co-published by Cornell University, INSEAD, World Intelectual Property Organization.

[3] European Commision, (2013). Enterprise and Industry. SBA Fact Sheet 2013, Albania.

[4] Gül, E. , \& Açıkalın, S. , (2008). An examination of the Fisher Hypothesis: the case of Turkey. Applied Economics, 40, 3227-3231. doi: 10. 1080/00036840600994112.

[5] Hall, B. H. , Lotti, F. , \& Mairesse, J. , (2009). Innnovatıon and productivity in SMEs: empirical evidence for Italy. Small Business Economics, 33, 13-33. doi: DOI 10. 1007/s11187-009-9184-8.

[6] Hill, R. C. , Griffiths E. W. , \& Lim, G. C. , (2008). Using eviews for principles of econometrics. USA, Wiley.

[7] IDRA Research \& Consulting, (2011). Financial and Non-Financial Tools supporting SMEs. Italian Embassy Office for Development Cooperation, Tirana.

[8] Janz, N. , Lööf, H. , \& Peters, A. , (2004). Firm level innovation and productivity - is there a common story across countries? Problems and Prespectives in Management, 2, 1-22. 
[9] Johansen, S. \& Juselius, K. (1990). Maximum likelihood estimation and inference on cointegration - with applications to the demand for money. Oxford Bulletin of Economics and Statistics, 52 (2), 169-210.

[10] Johansen, S. (1988). Statistical analysis of cointegration vectors. Journal of Economic Dynamics and Control, $12,231-254$.

[11] Keskin, H. , \& Şentürk, C. , (2010). The Importance Of Small And Medium-Sized Enterprises (SMEs) In Economies: Swot Analyses Of The Sme Sector In Turkey And Albania, Niğde Üniversitesi IIBF Dergisi, 3 (1) (2010), 116-132.

[12] Lööf, H. , \& Heshmati, A. , (2002). Knowledge capital and performance heterogenity: A firm level innovation study. International Journal of Production Economics, 76 (1), 61-85.

[13] Mairesse, J. , \& Mohnen, P. , (2005). The importance of R\&D for innovation: A reassessment using French Survey Data. The Journal of Technology Transfer, 30 (1-2), 183-197.

[14] Mucollari, H. , Dumi, A. , \& Kukaj, L. , (2012). SMEs and Enterprises, Represent Potential Employment and Economic Growth in Emerging Economies in Albanian Development, Mediterranean Journal of Social Sciences Vol. 3, doi: Doi: 10. 50901/mjss. 2012. v3n11p63.

[15] Praag C. M. , \& Versloot, P. H. , (2007). What is the value of entrepreneurship? A review of recent research. Small Business Economics, 27, 351-382. doi: DOI 10. 1007/s11187-007-9074-X.

[16] Scalera, F. , \& Uruci, E. , (2011). Internationalisation Strategies of SMEs in Albania. The Influence of Business Climate. Developments and Prospects, International Journal of Economics and Research, 162 - 176.

[17] Shkurti, L. , (2013). Strategy Implementation Challenges in Albanian Organizations, European Journal of Business and Management, Vol. 5, no. 28, 26-31.

[18] World Bank (2013). Western Balkans Regional R\&D Strategy for Innovation, Country Paper Series, Albania .

[19] World Developement Indicator (2015). Retrived March 12, 2015 from World Bank Database. http://data. worldbank. org/country/albania .

[20] Xhepa, S. , (2006). Competitiveness \& the SME developement in Albania, Institute for Contemporary Studies (ICS), Tirana, Albania. 